\title{
PENGARUH PENAMBAHAN TEMPE DAN TEPUNG TAPIOKA TERHADAP KARAKTERISTIK FISIKOKIMIA DAN HEDONIK NUGGET NANGKA MUDA (Artocarpus heterophyllus LMK)
}

\section{Physicochemical Characteristics and Hedonic Unripe Jackfruit Nugget (Artocarpus heterophyllus LMK) with Addition of Tempe and Tapioca Flour}

\author{
Uswatun Hasanah, Millatul Ulya*, Umi Purwandari \\ Program Studi Teknologi Industri Pertanian, Universitas Trunojoyo Madura \\ Jl. Raya Telang, PO BOX 2 Kamal, Bangkalan-Madura \\ *Penulis Korespondensi, Email: millatul.utm@gmail.com
}

\begin{abstract}
ABSTRAK
Penelitian dilakukan untuk mengetahui pengaruh penambahan proporsi tempe, tapioka dan interaksi kedua faktor terhadap karakteristik fisikokimia dan hedonik nugget nangka muda, serta untuk mengetahui perlakuan terbaiknya. Rancangan penelitian yang digunakan adalah Rancangan Acak Lengkap 2 faktor yaitu proporsi tempe $(0 \%, 10 \%, 20 \%$ dan $30 \%$ ) dan proporsi tapioka (10\% dan $20 \%$ ). Parameter uji antara lain tekstur, kadar air, kadar lemak dan protein serta uji hedonik. Hasil penelitian menunjukkan proporsi tempe berpengaruh nyata terhadap hardness, chewiness, kadar protein dan lemak nugget nangka muda. Proporsi tapioka memberi pengaruh signifikan terhadap kadar air, hardness, cohesiveness, springiness, gumminess, chewiness, kadar protein, kadar lemak dan tekstur (hedonik/kesukaan). Interaksi antara proporsi tempe dan tapioka berpengaruh terhadap kadar protein dan kadar lemak. Perlakuan terbaik yaitu proporsi tempe 30\% dan tapioka $20 \%$ dihasilkan nugget dengan kadar air sebesar $36.75 \%$, kadar protein sebesar $5.09 \%$ dan kadar lemak sebesar $9.78 \%$.
\end{abstract}

Kata Kunci : Nangka Muda, Nugget, Tempe, Tapioka

\begin{abstract}
This study aims to determine the effect of the proportion of tempe, tapioca and their interactions on the physicochemical and hedonic characteristics of unripe jackfruit nuggets, and to determine the best treatment. The study used completely randomized design with 2 factors, namely the proportion of tempe $(0 \%, 10 \%, 20 \%$ and $30 \%)$ and the proportion of tapioca (10\% and 20\%). Test parameters include water content, texture, fat content, protein content and hedonic test. The results showed the proportion of tempe significantly affected hardness, chewiness, protein content and fat content. Tapioca proportion significantly affects water content, hardness, cohesiveness, springiness, gumminess, chewiness, protein content, fat content and texture (hedonic). The interaction between the proportion of tempe and tapioca affects the protein content and fat content. The best treatment is nuggets with the proportion of tempe $30 \%$ and tapioca $20 \%$ with water content, protein content and fat content respectively $36.75 \% ; 5.09 \%$ and $9.78 \%$.
\end{abstract}

Keywords: Nugget, Tapioka,Tempe, Unripe jackfruit

\section{PENDAHULUAN}

Nangka muda adalah salah satu komoditas hasil pertanian dengan tingkat ketersediaannya yang melimpah. Nangka muda memiliki beberapa kandungan gizi yaitu karbohidrat $23.50 \%$, protein $1.72 \%$, lemak $0.64 \%$ dan air $76.20 \%-85.20 \%$ (Tejpal dan Parle, 2016). Ketersediaan nangka yang cukup melimpah di daerah Jawa Timur mencapai 
116.495 ton/tahun dan di Indonesia mencapai 699.495 ton/tahun (BPS, 2015) dan tidak disertai pengolahan yang optimal menjadikan nangka muda mudah sekali mengalami kerusakan.

Perkembangan teknologi yang semakin pesat membuat nangka muda tidak hanya diolah menjadi produk olahan lodeh, pepes dan gudeg saja, namun juga bisa diolah menjadi aneka produk olahan modern yang lebih awet, antara lain sebagai bahan substitusi dalam pembuatan abon ikan gabus (Prihandoko dan Marwati, 2015), dendeng (Muljawan dan Untung, 2017), bahan dalam pembuatan daging iga tiruan (Prianto, 2014) Nangka muda juga telah dimanfaatkan oleh Nisa (2013) sebagai sustitusi dalam pembuatan nugget ayam. Beberapa pemanfaatan nangka muda tersebut masih banyak dikombinasikan dengan unsur hewani sehingga tidak semua kalangan dapat mencoba aneka produk olahan tersebut. Oleh karena itu, perlu adanya suatu inovasi pengolahan dalam meningkatkan nilai serta gizi nangka muda, salah satunya adalah dengan mengolahnya menjadi nugget namun dengan kombinasi bahan nabati.

Nugget menjadi salah satu jenis makanan yang cukup disukai masyarakat dari kalangan anak-anak hingga remaja. Nugget yang dijual di pasaran umumnya terbuat dari daging sapi dan daging ayam. Beberapa orang ada yang tidak menyukai olahan daging misalnya kalangan vegetarian. Nangka muda sendiri memiliki tekstur yang menyerupai daging dan rendah lemak, jika nangka muda ini diolah menjadi nugget sudah pasti baik kalangan vegetarian maupun kalangan non vegetarian dapat mengonsumsinya.

Kadar protein pada nangka muda sangatlah rendah yaitu $1.72 \%$ per 100 gramnya. Untuk meningkatkan kandungan protein pada nugget nangka muda maka ditambahkan tempe dalam proses pengolahannya. Berdasarkan penelitian Jannah et al. (2016) penambahan tempe kedelai pada abon nangka muda sebanyak $25 \%$ dan $35 \%$ dapat meningkatkan kandungan protein abon yaitu $19.26 \%$ dan $39.40 \%$.

Kandungan air pada nangka yang cukup tinggi menjadikan tekstur nugget nangka muda menjadi lebih lembek, sehingga memerlukan penambahan filler untuk pengikatan air serta memperbaiki tekstur nugget nangka muda agar lebih padat. Filler berbahan tepung tapioka dianggap cukup efektif dalam memperbaiki tekstur nugget nangka muda, karena pati ini memiliki kemampuan mengikat air yang tinggi sehingga nugget nangka yang dihasilkan memiliki tekstur yang lebih padat. Daya ikat air tepung tapioka dalam pembuatan nugget ayam petelur afkir diketahui sebesar $52.17 \%$ dengan keempukan sebesar $1.02 \%$, lebih tinggi dibandingkan tepung sagu, maizena dan beras ketan (Komansilan, 2015).

Penelitian ini bertujuan untuk mengetahui proporsi terbaik dalam menambahkan tempe dan filler dalam meningkatkan karakteristik fisik, kimia serta sensoris nugget nangka muda. Hasil penelitian ini diharapkan dapat mengoptimalkan pemanfaatan nangka muda menjadi produk olahan pangan yang disukai konsumen.

\section{BAHAN DAN METODE}

\section{Bahan}

Bahan baku yang digunakan adalah nangka muda, tempe, telur, susu, tapioka, garam, bawang merah, bawang putih, air, merica, tepung panir dan minyak.

\section{Alat}

Alat yang digunakan adalah timbangan analitik, meat grinder, blender, pisau, baskom, dandang, loyang, kompor, cawan petri, kertas minyak, kain saring, kertas saring, benang, gelas ukur, mortal, pastle dan pengaduk.

\section{Desain Penelitian}

Desain penelitian yang digunakan adalah Rancangan Acak Lengkap Faktorial dengan 2 faktor yaitu proporsi tempe dan proporsi filler. Jumlah perlakuan adalah 8 perlakuan diulang 3 kali sehingga total ada 24 unit percobaan. 
Tabel 1. Rancangan Percobaan Nugget Nangka Muda

\begin{tabular}{lcc}
\hline Proporsi & \multicolumn{2}{c}{ Bahan Pengisi/ Filler } \\
\cline { 2 - 3 } Tempe & $\mathbf{1 0 \%}(\mathrm{B} 1)$ & $\mathbf{2 0} \%(\mathrm{~B} 2)$ \\
\hline $0 \%(\mathrm{~A} 0)$ & $\mathrm{A} 0 \mathrm{~B} 1$ & $\mathrm{~A} 0 \mathrm{~B} 2$ \\
$10 \%(\mathrm{~A} 1)$ & $\mathrm{A} 1 \mathrm{~B} 1$ & $\mathrm{~A} 1 \mathrm{~B} 2$ \\
$20 \%(\mathrm{~A} 2)$ & $\mathrm{A} 2 \mathrm{~B} 1$ & $\mathrm{~A} 2 \mathrm{~B} 2$ \\
$30 \%(\mathrm{~A} 3)$ & $\mathrm{A} 3 \mathrm{~B} 1$ & $\mathrm{~A} 3 \mathrm{~B} 2$ \\
\hline
\end{tabular}

\section{Tahapan Penelitian}

Penelitian dilaksanakan dengan dua tahap, tahap pertama yaitu tahap pembuatan Nugget Nangka Muda, dan selanjutnya tahap analisis fisikokimia dan hedonik nugget nangka muda. Proses pembuatan nugget nangka muda dimulai dengan mengupas, memotong, mencuci, dan mengukus nangka muda selama 30 menit, menghaluskan bumbubumbu, memeras nangka muda menggunakan kain saring kemudian menggilingnya menggunakan meat grinder. Selanjutnya menggiling tempe menggunakan meat grinder.

Menimbang masing-masing bahan kemudian dicampur hingga kalis. Menuangkan adonan nugget secara rata pada loyang yang telah dilapisi kertas minyak. Mengukus adonan selama 45 menit kemudian didinginkan selama 10 menit lalu dipotong menggunakan ukuran sebesar $3 \times 0.50 \times 1 \mathrm{~cm}$.

\section{Parameter Penelitian}

Parameter fisikokimia meliputi pengujian dengan metode oven kering untuk mengetahui nilai kadar air, metode Kjeldahl untuk pengujian kadar protein dan metode soxhlet untuk pengujian kadar lemak (Sumantri, 2007), dan analisis tekstur menggunakan texture analyzer meliputi parameter hardness, springiness, cohesiveness, gumminess dan chewiness (Rianti, 2008 dalam Iswara dkk, 2019). Uji sensori dilaksanakan menggunakan metode Hedonic Scale Score dengan parameter uji rasa, tekstur, aroma, warna dan kesukaan keseluruhan (Setyaningsih dkk, 2010).

\section{Analisis Data}

Analisis data yang digunakan adalah ANOVA (Analysis of Variance) dengan taraf beda nyata $(p<0,05)$ dengan bantuan software SPSS 16. Apabila hasil dari pengujian menggunakan ANOVA berpengaruh signifikan maka dilanjutkan dengan uji Duncan. Data yang diperoleh juga akan digunakan dalam sistem pengambilan keputusan perlakuan terbaik menggunakan metode CPI/Comparative Performance Index (Marimin, 2004).

\section{HASIL DAN PEMBAHASAN}

\section{Uji Fisikokimia Nugget Nangka Muda}

Nugget nangka muda diuji fisikokimia menggunakan 8 parameter uji yaitu, kadar air, hardness, springiness, cohesiveness, gumminess, chewiness, kadar protein dan kadar lemak. Hasil pengaruh proporsi tempe terhadap karakteristik fisikokimia nugget nangka muda dapat dilihat pada Tabel 2, pengaruh proporsi tapioka terhadap karakteristik fisikokimia nugget nangka muda pada Tabel 3, dan pengaruh interaksi keduanya pada Tabel 4.

Tabel 2. Pengaruh Proporsi Tempe terhadap Karakteristik Fisikokimia Nugget Nangka Muda

\begin{tabular}{ccccc}
\hline $\begin{array}{c}\text { Proporsi Tempe : } \\
\text { Nangka Muda (\%) }\end{array}$ & Hardness (g) & Chewiness & Kadar Protein (\%) & Kadar Lemak (\%) \\
\hline $0: 100$ & $1381.92^{\mathrm{b}}$ & $457.52^{\mathrm{ab}}$ & $2.24^{\mathrm{a}}$ & $5.52^{\mathrm{a}}$ \\
$10: 90$ & $1119.89^{\mathrm{a}}$ & $360.92^{\mathrm{a}}$ & $4.55^{\mathrm{b}}$ & $5.94^{\mathrm{b}}$ \\
$20: 80$ & $1118.11^{\mathrm{ab}}$ & $475.03^{\mathrm{b}}$ & $4.69^{\mathrm{c}}$ & $7.27^{\mathrm{c}}$ \\
$30: 70$ & $1265.85^{\mathrm{b}}$ & $507.71^{\mathrm{b}}$ & $4.89^{\mathrm{d}}$ & $8.32^{\mathrm{d}}$ \\
\hline
\end{tabular}

Ket : Angka dengan huruf yang sama menunjukkan tidak berbeda nyata 
Pengaruh Penambahan Tempe dan Tepung Tapioka - Hasanah, dkk Jurnal Pangan dan Agroindustri Vol.8 No.3: 154-162, Juli 2020

Tabel 3. Pengaruh Proporsi Tapioka terhadap Karakteristik Fisikokimia Nugget Nangka Muda

\begin{tabular}{ccccccccc}
\hline $\begin{array}{c}\text { Proporsi } \\
\text { Tapioka } \\
(\%)\end{array}$ & $\begin{array}{c}\text { Kadar } \\
\text { Air }(\%)\end{array}$ & $\begin{array}{c}\text { Hardness } \\
(\mathbf{g})\end{array}$ & $\begin{array}{c}\text { Springi } \\
\text { ness }\end{array}$ & $\begin{array}{c}\text { Cohesiven } \\
\text { ess }\end{array}$ & $\begin{array}{c}\text { Gummi- } \\
\text { ness }\end{array}$ & $\begin{array}{c}\text { Chewi- } \\
\text { ness }\end{array}$ & $\begin{array}{c}\text { Kadar } \\
\text { Protein } \\
(\%)\end{array}$ & $\begin{array}{c}\text { Kadar } \\
\text { Lemak } \\
(\%)\end{array}$ \\
\hline 10 & $33.13^{\mathrm{a}}$ & $924.26^{\mathrm{a}}$ & $0.63^{\mathrm{a}}$ & $0.50^{\mathrm{a}}$ & $450.89^{\mathrm{a}}$ & $284.82^{\mathrm{a}}$ & $3.99^{\mathrm{a}}$ & $4.52^{\mathrm{a}}$ \\
20 & $36.75^{\mathrm{b}}$ & $1408.81^{\mathrm{b}}$ & $0.74^{\mathrm{b}}$ & $0.60^{\mathrm{b}}$ & $832.86^{\mathrm{b}}$ & $615.21^{\mathrm{b}}$ & $4.19^{\mathrm{b}}$ & $8.99^{\mathrm{b}}$ \\
\hline
\end{tabular}

Ket : Angka dengan huruf yang sama menunjukkan tidak berbeda nyata

Tabel 4. Pengaruh Interaksi Tempe dan Tepung Tapioka terhadap Karakteristik Fisikokimia Nugget Nangka Muda

\begin{tabular}{cccc}
\hline $\begin{array}{c}\text { Proporsi Tempe : } \\
\text { Nangka Muda (\%) }\end{array}$ & Proporsi Tapioka (\%) & Kadar Protein (\%) & Kadar Lemak (\%) \\
\hline $0: 100$ & 10 & $2.15^{\mathrm{e}}$ & $2.82^{\mathrm{f}}$ \\
$10: 90$ & & $4.49^{\mathrm{d}}$ & $3.46^{\mathrm{e}}$ \\
$20: 80$ & & $4.76^{\mathrm{c}}$ & $4.96^{\mathrm{d}}$ \\
$30: 70$ & 20 & $4.68^{\mathrm{bc}}$ & $6.86^{\mathrm{c}}$ \\
\hline $0: 100$ & & $2.33^{\mathrm{e}}$ & $8.22^{\mathrm{b}}$ \\
$10: 90$ & & $4.61^{\mathrm{c}}$ & $8.42^{\mathrm{b}}$ \\
$20: 80$ & & $4.73^{\mathrm{b}}$ & $9.57^{\mathrm{a}}$ \\
$30: 70$ & & $5.09^{\mathrm{a}}$ & $9.78^{\mathrm{a}}$ \\
\hline
\end{tabular}

Ket : Angka dengan huruf yang sama menunjukkan tidak berbeda nyata

Hasil uji kadar air menunjukkan, semakin tinggi proporsi tepung tapioka menyebabkan kandungan air pada nugget nangka muda juga semakin tinggi. Menurut Gunawan (2010) tepung tapioka mempunyai kadar amilopektin yang lebih tinggi apabila dibandingkan dengan tepung terigu. Ketika dipanaskan amilopektin ini akan mengembang menghasilkan kerapatan yang tinggi serta menghasilkan adonan yang lebih kompak sehingga mengakibatkan daya ikat air produk juga semakin besar.

Pada parameter nilai hardness, nilai yang diperoleh akan semakin kecil seiring dengan meningkatnya penambahan proporsi tempe. Kandungan serat pada tempe menyebabkan terhambatnya proses gelatinisasi pati tapioka (Illene, 2014). Gelatinisasi yang kurang maksimal menyebabkan ruang-ruang kosong pada nugget kurang terisi dan akhirnya tekstur nugget menjadi kurang keras dan kurang padat (Puspitasari, 2008). Semakin tinggi proporsi tapioka maka nilai hardnessnya juga semakin tinggi. Semakin banyaknya proporsi tapioka mengindikasikan kandungan pati yang ada di dalamnya juga semakin banyak. Adanya glatinisasi pati akan mengisi ruang-ruang kosong nugget sehingga mengakibatkan tekstur menjadi semakin padat dan keras (Suseno et al., 2007).

Pada nilai springiness menunjukkan semakin tinggi proporsi tapioka maka nilai springiness juga semakin tinggi. Tepung tapioka memiliki sifat yang kenyal karena kandungan amilosa dan amilopektin. Melalui proses gelatinisasi granula pati pada tapioka akan mengembang sehingga mampu meningkatkan elastisitas produk (Fitriyani, 2017).

Hasil analisis cohesiveness menunjukkan semakin banyak proporsi tapioka maka nilai cohesiveness juga semakin tinggi. Tepung tapioka memiliki banyak pati dengan kandungan amilosa dan amilopektin yang mampu berinteraksi secara baik dengan air dan protein pada nugget (Suseno et al., 2007). Proses pengukusan nugget mengakibatkan terjadinya proses gelatinisasi yang mampu mengisi ruang-ruang antar komponen bahan sehingga menghasilkan adonan yang lebih kompak.

Pada parameter nilai gumminess menunjukkan semakin tinggi proporsi tapioka yang ditambahkan maka mengakibatkan nilai gumminess yang tinggi. Semakin tingginya proporsi tapioka mengindikasikan kadar amilosa pada nugget juga semakin tinggi sehingga nilai gumminess yang dihasilkan semakin tinggi pula. Hal tersebut sejalan dengan penelitian Fitriyani (2017) yang menyebutkan bahwa semakin tinggi proporsi tepung ubi jalar ungu dalam pembuatan bakso ikan mengakibatkan nilai gumminess bakso juga semakin tinggi.

Penelitian terhadap nilai chewiness menunjukkan semakin besar penambahan proporsi tempe maka nilai chewiness dari nugget nagka muda meningkat. Proses pengukusan atau pemanasan menyebabkan pati dan protein yang ada pada tempe mengikat air dan komponen di sekitarnya. Pati dan protein ini juga akan memenuhi ruang 
kosong yang ada pada matriks produk. Hal tersebut menyebabkan struktur matrik menjadi lebih rapat dan padat sehingga untuk menghancurkannya membutuhkan daya kunyah yang lebih besar (Prijambodo et al., 2014). Semakin tinggi proporsi tapioka maka nilai chewiness nugget juga semakin tinggi. Rosyidah (2017) menyebutkan kandungan amilopektin pada tapioka mampu meningkatkan nilai elastisitas dan kelengketan produk, semakin tinggi proporsi tapioka yang ditambahkan maka akan meningkatkan daya kunyah produk.

Pada kadar protein nugget nangka muda menunjukkan nilai yang semakin meningkat seiring dengan tingginya penambahan proporsi tempe. Perlu diketahui tempe sendiri memiliki protein yang lebih rendah dari kedelai. Menurut Departemen Kesehatan Republik Indonesia (1995) kandungan protein kedelai dan tempe per 100 gramnya adalah $40.4 \%$ dan $12.5 \%$. Adanya pengurangan protein dari kedelai menjadi tempe disebabkan adanya denaturasi protein sebagai akibat dari proses pengolahan tempe seperti perendaman dan perebusan (Muthmainna et al., 2016). Semakin besar proporsi tapioka yang ditambahkan pada nugget maka kadar proteinnya juga semakin tinggi. Tabloid Senior No. 287/14-20 (2005) dalam Djuwardi (2009), kandungan protein tepung tapioka per 100 gramnya adalah $0.5 \%$. Jika nugget dengan proporsi tapioka $10 \%$ menghasilkan kadar protein sebesar $3.99 \%$, maka apabila proporsinya ditambah menjadi $20 \%$ akan menghasilkan kadar protein sebesar $4.12 \%$. Kadar protein nugget nangka muda dengan proporsi tapioka $20 \%$ sebesar 4.19\% dianggap mendekati angka 4.12\%. Selain itu, pada uji kadar protein, semakin besar proporsi tempe dan tapioka maka kadar protein nugget juga semakin besar. Tekstur nugget menjadi lebih padat karena protein tempe akan berikatan kuat dengan tepung tapioka menyelubungi lemak sehingga akan terbentuk suatu emulsi (Kanoni et al., 2011).

Hasil analisis kadar lemak nugget nangka muda menunjukkan semakin tinggi proporsi tempe maka kadar lemaknya juga semakin tinggi. Hasil analisa kadar lemak tersebut sesuai dengan penelitian Afrisanti (2010), yaitu semakin banyak proporsi tepung tempe yang ditambahkan pada nugget daging kelinci maka kadar lemaknya juga semakin banyak dan menyebabkan kadar lemaknya berbeda nyata. Umumnya kadar lemak suatu bahan akan menurun setelah melalui perebusan atau pengukusan. Penurunan ini terjadi karena adanya kerusakan struktur lemak akibat penggunaan suhu tinggi (Sundari et al., 2015). Selain itu, penambahan proporsi tapioka yang semakin besar maka kadar lemak nugget nangka muda yang dihasilkan juga semakin besar. Tabloid Senior No. 287/14-20 (2005) dalam Djuwardi (2009), kandungan lemak tepung tapioka per 100 gramnya adalah $0.3 \%$. Jika nugget dengan proporsi tapioka $10 \%$ menghasilkan kadar lemak sebesar $4.52 \%$, maka apabila proporsinya ditambah menjadi $20 \%$ akan menghasilkan kadar lemak sebesar $4.60 \%$. Kadar lemak nugget nangka muda dengan proporsi tapioka $20 \%$ sebesar $8.99 \%$ sangat jauh dari angka 4.60\%. Tingginya selisih kadar lemak nugget nangka muda dengan proporsi tapioka $10 \%$ dan $20 \%$ ini diduga karena kurangnya ketelitian penguji pada saat pengujian kadar lemak. Penggunaan sampel uji yang sangat sedikit juga ikut mempengaruhi ketelitian penguji dalam memperoleh nilai kadar lemak yang valid. Analisis kadar lemak juga menunjukkan tingginya kadar lemak nugget hanya dipengaruhi oleh tingginya proporsi tapioka. Proporsi tapioka yang mengalami gelatinisasi akan membuka rongga-rongganya sebagai jalan keluar udara yang menguap, rongga inilah yang akan mengadsorbsi kandungan lemak bahan penyusun nugget nangka muda sehingga kadar lemaknya juga semakin tinggi (Ramadhani dan Erni, 2017).

\section{Karakteristik Hedonik Nugget Nangka Muda}

\section{Uji Hedonik terhadap Warna}

Gambar 1 menunjukkan makin tinggi proporsi tempe dan tapioka maka tingkat kesukaan panelis terhadap nugget juga semakin tinggi. skor tertinggi tingkat kesukaan warna adalah nugget dengan perlakuan A3B2, artinya panelis lebih menyukai warna nugget dengan proporsi tempe $30 \%$ dan tapioka $20 \%$. 


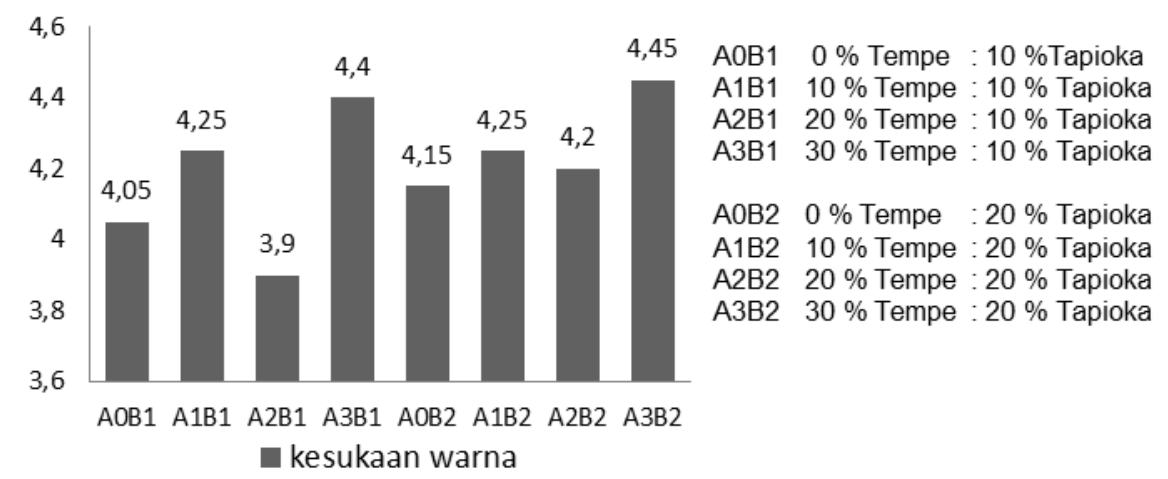

Gambar 1. Grafik Rerata Kesukaan Warna Nugget Nangka Muda

\section{Uji Hedonik terhadap Aroma}

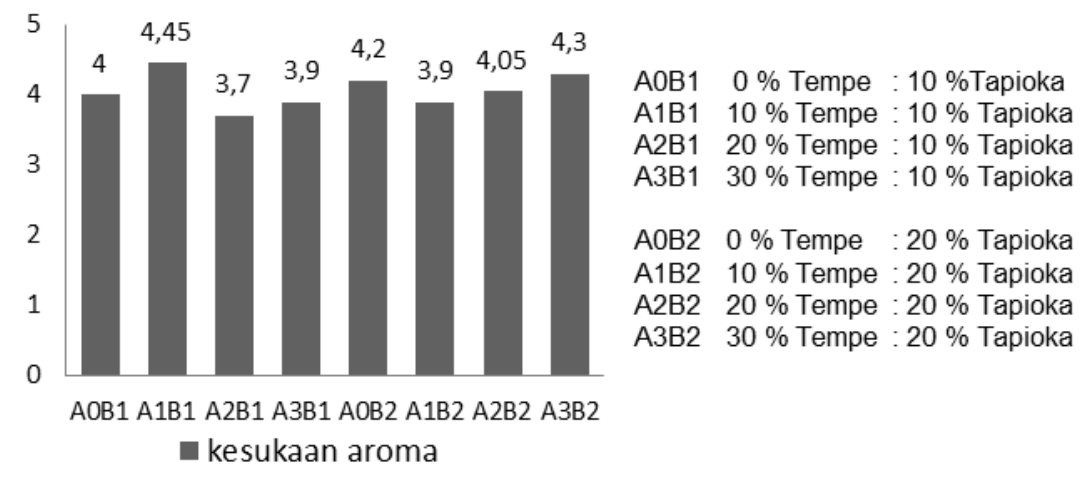

Gambar 2. Grafik Rerata Kesukaan Aroma Nugget Nangka Muda

Berdasarkan Gambar 2 tingginya grafik yang dihasilkan pada uji kesukaan terhadap warna nugget adalah hampir sama rata, artinya tingkat kesukaan panelis terhadap aroma pada setiap perlakuan adalah hampir sama. Skor tertinggi kesukaan aroma adalah nugget dengan perlakuan A1B1, artinya panelis lebih menyukai aroma nugget dengan proporsi tempe $10 \%$ dan tapioka $10 \%$.

\section{Uji Hedonik terhadap Rasa}

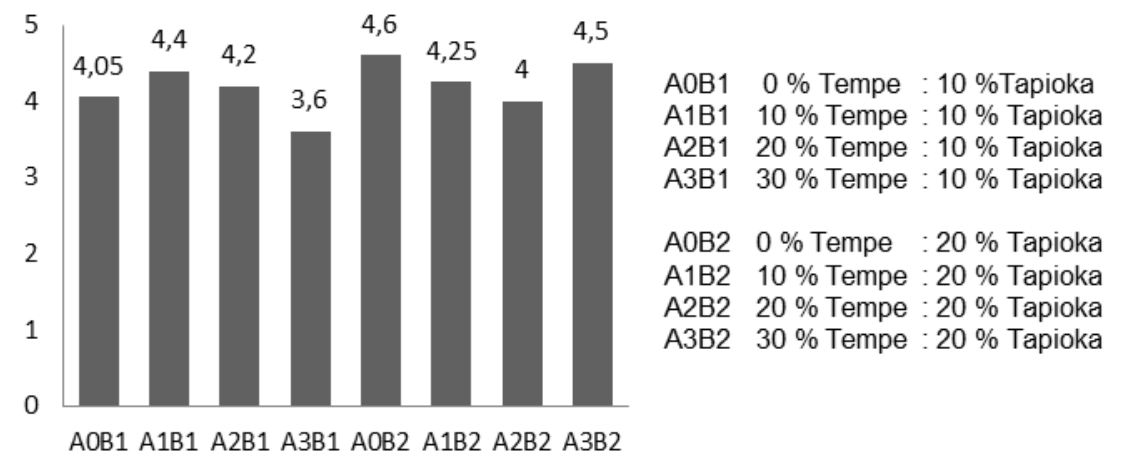

kesukaan rasa

Gambar 3. Grafik Rerata Kesukaan Rasa Nugget Nangka Muda

Berdasarkan Gambar 3 tingginya grafik yang dihasilkan pada uji kesukaan terhadap rasa nugget adalah hampir sama rata, artinya tingkat kesukaan panelis terhadap rasa pada setiap perlakuan adalah hampir sama. Rasa yang ada pada nugget tidak dipengaruhi oleh proporsi tapioka dan tempe melainkan berasal dari bumbu-bumbu yang ditambahkan pada 
nugget. Proporsi bumbu pada setiap perlakuan adalah sama sehingga akan menghasilkan rasa yang sama pula pada setiap perlakuan.

\section{Uji Hedonik terhadap Tekstur}

Tabel 5 menunjukkan semakin tinggi proporsi tapioka maka skor kesukaan panelis terhadap tekstur nugget juga semakin tinggi. Tepung tapioka memiliki banyak pati dengan kandungan amilosa dan amilopektin yang mampu berinteraksi secara baik dengan air dan protein pada nugget (Suseno el al. 2007). Proses pengukusan nugget mengakibatkan terjadinya proses gelatinisasi yang mampu mengikat air nangka muda yang cenderung tinggi serta mampu mengisi ruang-ruang antar komponen bahan sehingga menghasilkan adonan yang lebih kompak.

Tabel 5. Pengaruh Proporsi Tapioka terhadap Kesukaan Tekstur Nugget Nangka Muda

\begin{tabular}{cc}
\hline $\begin{array}{c}\text { Proporsi Tapioka } \\
(\%)\end{array}$ & Tekstur \\
\hline 10 & $4.11^{\mathrm{a}}$ \\
20 & $4.49^{\mathrm{b}}$ \\
\hline
\end{tabular}

Ket : Angka dengan huruf yang sama memiliki arti tidak berbeda nyata

\section{Uji Hedonik terhadap Keseluruhan}

Berdasarkan Gambar 4 rata-rata skor kesukaan keseluruhan berada pada angka 4, artinya tingkat kesukaan keseluruhan panelis terhadap nugget nangka muda adalah hampir sama. Berdasarkan Gambar 4 skor tertinggi tingkat kesukaan keseluruhan berada pada perlakuan A0B2, artinya panelis lebih menyukai secara keseluruhan nugget dengan proporsi tempe $0 \%$ dan tapioka $20 \%$.

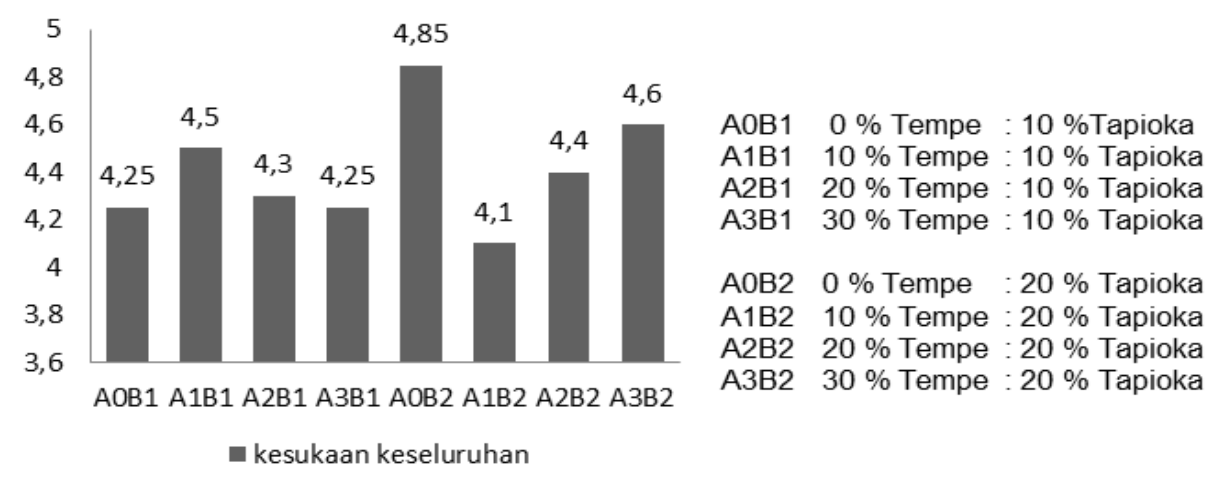

Gambar 4. Grafik Rerata Kesukaan Keseluruhan Nugget Nangka Muda

\section{Perlakuan Terbaik berdasarkan Metode CPI}

Tabel 6. Metode CPI pada Nugget Nangka Muda

\begin{tabular}{|c|c|c|c|c|c|c|c|c|}
\hline \multirow[b]{2}{*}{ Alternatif } & \multicolumn{7}{|c|}{ Kriteria } & \multirow{2}{*}{$\begin{array}{c}\text { Nilai } \\
\text { Alternatif }\end{array}$} \\
\hline & $\begin{array}{c}\text { Kadar } \\
\text { Air }\end{array}$ & $\begin{array}{c}\text { Kadar } \\
\text { Protein }\end{array}$ & $\begin{array}{l}\text { Kadar } \\
\text { Lemak }\end{array}$ & Cohesiveness & Gumminess & Springiness & Tekstur & \\
\hline A0B1 & 100.00 & 100.00 & 100.00 & 100.00 & 162.01 & 100.00 & 109.10 & 108.02 \\
\hline A1B1 & 92.07 & 208.84 & 81.50 & 113.33 & 100.00 & 105.00 & 109.09 & 120.09 \\
\hline A2B1 & 87.74 & 216.74 & 56.86 & 113.33 & 158.65 & 105.00 & 109.09 & 125.48 \\
\hline A3B1 & 95.39 & 217.67 & 41.11 & 117.78 & 163.60 & 110.00 & 100.00 & 126.16 \\
\hline $\mathrm{A} 0 \mathrm{~B} 2$ & 86.52 & 108.37 & 34.31 & 124.44 & 289.47 & 115.00 & 114.29 & 126.32 \\
\hline A1B2 & 84.93 & 214.42 & 33.49 & 131.11 & 227.42 & 125.00 & 107.79 & 137.85 \\
\hline A2B2 & 82.29 & 220.00 & 29.47 & 144.44 & 264.11 & 131.67 & 118.18 & 147.97 \\
\hline A3B2 & 83.78 & 236.74 & 28.83 & 131.11 & 298.21 & 126.67 & 123.38 & 151.38 \\
\hline $\begin{array}{c}\text { Bobot } \\
\text { Kriteria }\end{array}$ & 0,1 & 0,15 & 0,05 & 0,2 & 0,1 & 0,2 & 0,2 & \\
\hline
\end{tabular}


Tabel 6 menunjukkan nilai alternatif tertinggi adalah nugget dengan perlakuan A3B2, artinya berdasarkan metode CPI perlakuan terbaik nugget nangka muda adalah nugget dengan penambahan tempe $30 \%$ dan tapioka $20 \%$.

\section{SIMPULAN}

Proporsi tempe berpengaruh nyata pada kadar protein, hardness, chewiness, dan kadar lemak. Proporsi tapioka berpengaruh signifikan pada kadar air, kadar protein, hardness, springiness, cohesiveness, gumminess, chewiness, kadar lemak dan tekstur. Interaksi antara proporsi tempe dan proporsi tapioka berpengaruh signifikan pada kadar lemak dan kadar protein. Berdasarkan metode CPI perlakuan terbaik nugget nangka muda adalah A3B2 yaitu nugget dengan proporsi tempe $30 \%$ dan tapioka $20 \%$. Kadar air, kadar protein dan kadar lemak berturut-turut yaitu $36.75 \% ; 5.09 \%$ dan $9.78 \%$.

\section{DAFTAR PUSTAKA}

Afrisanti, D.W. 2010. Kualitas Kimia dan Organoleptik Nugget Daging Kelinci dengan Penambahan Tepung Tempe. [Skripsi]. Universitas Sebelas Maret.

Badan Pusat Statistik Indonesia. 2015. Statistik Tanaman Buah-buahan dan Sayuran Tahunan. Badan Pusat Statistik Indonesia. ISSN: 2088-8406.

Departemen Kesehatan Republik Indonesia. 1995. Daftar Komposisi Zat Gizi Pangan Indonesia. Jakarta: Departemen Kesehatan.

Djuwardi, A. 2009. Cassava. Jakarta: Grasindo. ISBN 978-979-025-745-0.

Fitriyani, E. 2017. Tepung Ubi Jalar sebagai Bahan Filler Pembentuk Tekstur Bakso Ikan. Jurnal Galung Tropika. 6:1, 19-32.

Gunawan, F.N. 2010. Pengaruh Kombinasi Filler (Tepung Tapioka-Tepung Beras Ketan dan Tepung Terigu-Tepung Beras Ketan) dan Bentuk terhadap Karakteristik Kerupuk Putih Telur. [Skripsi]. Semarang: Universitas Katolik Soegijapranata.

Illene, F. 2014. Sifat Fisikokimia dan Organoleptik Nugget Ikan Tuna dengan Penambahan Maizena dan Tepung Menjes. [Skripsi]. Universitas Katolik Widya Mandala Surabaya.

Iswara, J. A, Julianti, E dan Nurminah, M. 2019. Karakteristik Tekstur Roti Manis dari Tepung, Pati, Serat dan Pigmen Antosianin Ubi Jalar Ungu. Jurnal Pangan dan Agroindustri 7:4, 12-21.

Jannah, U.Q.A.N., Darimiyya, H. dan Abdul, A. J. 2016. Karakteristik Sensoris dan Kimia pada Abon Nangka Muda (Artocarpus heterophyllus) dengan Penambahan Tempe. Agrointek. 10:1, 48-54.

Kanoni, S., Priyanto, T. dan Anggita, E.L. 2011. Karakteristik Nugget Analog Kedelai Hitam (Glycine max (L.) Merr). Seminar Nasional. ISBN: 978-979-17342-0-2.

Komansilan, S. 2015. Pengaruh Penggunaan Beberapa Jenis Filler terhadap Sifat Fisik Chicken Nugget Ayam Petelur Afkir. Jurnal Zootek. 35:1, 106-116. ISSN 0852-2626.

Marimin. 2004. Teknik dan Aplikasi Pengambilan Keputusan Kriteria Majemuk. Penerbit Grasindo. Jakarta

Muljawan, R.E. dan Untung, S. 2017. Potensi Ekonomi Produk Abon dan Dendeng Nabati. Jurnal Akses Pengabdian Indonesia. 1:2, 32-38.

Muthmainna, Sri, M.S. dan Supriadi. 2016. Pengaruh Waktu Fermentasi terhadap Kadar Protein dari Tempe Biji Buah Lamtoro Gung (Leucaena leucocephala. Jurnal Akademika Kimia. 5:1, 50-54.

Nisa, T.K. 2013. Pengaruh Substitusi Nangka Muda (Artocarpus heterophyllus Lmk) terhadap Kualitas Organoleptik Nugget Ayam. Food Science and Culinary Education Journal. 2:1, 63-71.

Prianto, A. P. 2014. Rekayasa Pembuatan Daging Iga Tiruan dari Nangka Muda (Artocarpus Heterophyllus) sebagai Hidangan Main Course "Sintetic Rib with Mushroom Sauce". E-journal Boga. 3:3, 51-57. 
Prihandoko, S. dan Marwati. 2015. Pengaruh Substitusi Nangka Muda (Artocarpus heterophyllus) terhadap Sifat Kimia dan Sensoris Abon Ikan Gabus ( striatus. Jurnal Teknologi Pertanian Universitas Mulawarman. 10:2, 58-64.

Prijambodo, O.M., Chatarina, Y.T. dan Anita, M.S. 2014. Karakteristik Fisikokimia dan Organoleptik Sosis Ayam dengan Proporsi Kacang Merah Kukus dan Minyak Kelapa Sawit. Jurnal Teknologi Pangan dan Gizi. 13:1, 6-11.

Puspitasari, D. 2008. Kajian Substitusi Tapioka dengan Rumput Laut (Eucheuma cottoni) pada Pembuatan Bakso. [Skripsi]. Universitas Sebelas Maret.

Ramadhani, F. dan Erni, S.M. 2017. Pengaruh Jenis Tepung Penambahan Perenyah terhadap Karakteristik Fisikokimia dan Organoleptik Kue Telur Gabus Keju. Jurnal Pangan dan Agroindustri. 5:1, 38-47.

Rosyidah, A. 2017. Karakteristik Fisikokimia Keju Cedar Olahan dengan Penambahan Filler Berbasis Singkong. [Skripsi]. Institut Pertanian Bogor.

Setyaningsih, D, Apriyantono, A dan Puspitasari, M. A. 2010. Analisis Sensori untuk Industri Pangan dan Agro. IPB Press. Bogor.

Sumantri, R. A. 2007. Analisis Makanan. Gajah Mada University Press. Yogyakarta.

Sundari, D., Almasyhuri dan Astuti, L. 2015. Pengaruh Proses Pemasakan terhadap Komposisi Zat Gizi Bahan Pangan Sumber Protein. Media Litbangkes. 25:4, 235-242.

Suseno, T.I.P., Sutarjo, S. dan Ina, M.F. 2007. Pengaruh Jenis Bagian Daging Babi dan Penambahan Tepung Terigu terhadap Sifat Fisikokimiawi Pork Nugget. Jurnal Teknologi Pangan dan Gizi. 6:2, 15-25.

Tejpal, A. dan Parle, A. 2016. Jacfruit: a Health Boon. Int. J. Res. Ayurveda Pharm. 7:3, 5964. 